\title{
Cratonic lithospheric mantle: Is anything subducted?
} ARC National Key Centre for Geochemical Evolution and Metallogeny of Continents (www.es.mq.edu.au/ GEMOC), Department of Earth and
Planetary Sciences, Macquarie University, NSW 2109, Australia.E-mail: wgriffin@els.mq.edu.au

If the subcontinental lithospheric mantle (SCLM) formed through the repeated underthrusting of oceanic slabs, peridotitic SCLM should resemble oceanic peridotites, and mafic rocks (eclogites, s.l.) should be distributed throughout the SCLM. However, cratonic peridotites (both exposed massifs and xenoliths) differ markedly from oceanic and ophiolitic peridotites in their Fe-Cr-Al relationships and abundances of trace elements (Li and B) diagnostic of subduction. "Typical" cratonic peridotites have experienced extensive metasomatism; modelling of their refractory protoliths indicates high-degree melting at high $P$, perhaps a uniquely Archean process. Cratonic eclogites are strongly concentrated at the base of the depleted SCLM or at major layer boundaries, and are accompanied by intense meltrelated metasomatism in adjacent peridotites. This distribution, and the preservation of exsolution microstructures, suggest an origin by the ponding and cooling of magmas at a compositional/rheological boundary. Compositionally, cratonic eclogites are similar to Phanerozoic garnet pyroxenites that originated as cumulates of high-Al pyroxenes and as reaction zones between melts and peridotite wall rocks. Eu anomalies in peridotitic garnets from the lithospheric mantle are unlikely to reflect plagioclase fractionation, but may be redox-related metasomatic signatures; such anomalies in eclogitic minerals or whole rocks are thus not prima facie evidence of low-P origin. Mg-isotope fractionation in high-T mantle xenoliths indicates that stable-

\section{Introduction}

The origin of the thick, refractory roots of subcontinental lithospheric mantle (SCLM) underlying most of the world's Archean cratons is a key question in modern Earth Sciences. Controversy centres around two end-member models: in one, the SCLM consists largely of oceanic slabs that have been progressively "stacked" beneath the early continents (Figure 1). In the other, most of the ancient, subcratonic SCLM represents buoyant residues of highpressure, high-degree melting that have risen from below (Griffin et al., 2004; references therein).

Xenoliths of eclogite (used here sensu latu, to include garnet pyroxenites with low-Na cpx) also occur in some kimberlites within Archean cratons. Schulze (1989) used the relative abundance of eclogitic vs peridotitic garnets in these kimberlites to estimate that eclogite might make up $<1 \%$ of the total volume of the cratonic SCLM. Despite these low abundances, eclogites have been assigned great importance in the debate on the origin of these ancient SCLM domains.

Eclogites, clearly formed by the high-P metamorphism of basaltic rocks, occur in some ophiolite sequences, where they are easily interpreted as subducted ocean floor. Other eclogites, clearly representing metamorphosed basalts or gabbros, are found in subducted continental crust within UHP terranes such as those in western Norway and eastern China. However, these eclogites were originally interpreted as mantle fragments, and were only widely recognised as crustally-derived rocks in the early 1980s (see review by Griffin, 1987).

The recognition of eclogite as a product of subduction processes has had a major effect on arguments about the origin of the cratonic SCLM. Over the last 10-15 years, earlier interpretations of the cratonic eclogites as deep-seated magmatic rocks intruded into the SCLM have been largely supplanted by arguments (based mainly on stable-isotope evidence) that the cratonic eclogites represent fragments of subducted sea floor (see a detailed review by Jacob, 2004).

This model has now reached the status of a "dominant paradigm", to the extent that suites of eclogite xenoliths with no obvious isotopic or compositional evidence for a low-P origin are described isotope variations (including $O$ and $C$ ) in cratonic eclogite suites may not be evidence of ocean-floor processes. Covariations between $C$ and $O$ isotope ratios suggest that high-T redoxrelated Rayleigh fractionation, and mixing processes involving carbonatitic melts, can explain the ranges of $\delta^{18} \mathrm{O}$ and $\delta^{13} \mathrm{C}$ in eclogite suites. There is thus little compelling evidence that any rocks in the cratonic SCLM represent unambiguous samples of subducted oceanic plates.

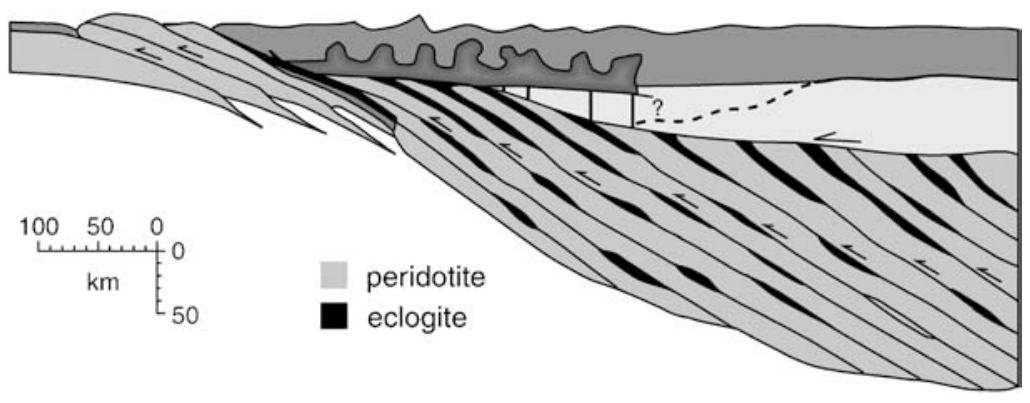

Figure 1 Model for generation of the SCLM by repeated stacking of subducted oceanic slabs beneath older continental crust. After Helmstedt and Gurney (1995). 
as subduction-related, and evidence (isotopic or microstructural) that conflicts with an oceanic origin is dismissed or explained away. Paradigms such as this are useful as long as they provoke new ways of examining data and testing evidence, but they lose their value when applied as universal solutions. In this paper, we re-examine some of the evidence for the subduction origin of cratonic eclogites and (briefly) peridotites; we conclude that little of this evidence can be regarded as diagnostic. Our aim is not to provide a comprehensive review, nor to criticise any individual studies. We simply wish to point out that the evidence for the subduction model for the cratonic SCLM is weaker than it might appear, and open to alternative interpretations.

\section{"SCLM stacking" and its implications}

Perhaps the most elegant presentation of the subduction-stacking model for generating the Archean SCLM was given by Helmstaedt and Gurney (1995; see also Hart et al., 1997). In this model (Figure 1), the SCLM has been formed by repeated underthrusting of oceanic slabs, which accumulate beneath older continental crust.

It should be noted that this process apparently does not occur on Earth today. Seismic tomography (e.g., Replumaz et al., 2004) shows subducting slabs at continental margins descending steeply into the upper mantle, eventually ponding at, or punching through, the $610 \mathrm{~km}$ discontinuity. Even in areas of relatively flat subduction, oceanic slabs can be seen delaminating and dropping into the depths, rather than clinging to underside of the crust and uppermost mantle. For the subduction-stacking model to be realistic, it must be argued that thicker, more depleted Archean slabs would have been more buoyant relative to the asthenospheric mantle than modern ones. This is not an obvious result, since the hotter Archean asthenosphere also would have been less dense than today's, and the two effects may essentially cancel one another out (cf Cooper et al., 2006; Poudjom Djomani et al., 2001; O'Reilly et al., 2001).

The subduction-stacking model as illustrated in Figure 1 has two major implications: (1) both peridotites and eclogites in the Archean SCLM should record evidence of low-P origin; (2) cratonic eclogites should be distributed throughout the SCLM (e.g., Hart et al., 1997).

\section{SCLM Peridotites - a low-P origin?}

The major-element compositions of Archean SCLM peridotites have been discussed in detail by Griffin et al. (1998, 1999). These peridotites differ in several important respects from those found in Phanerozoic oceanic environments, including abyssal oceanic peridotites, ophiolite sequences, and xenoliths from island-arc volcanoes. In Phanerozoic peridotite suites, $\mathrm{FeO}$ contents remain essentially constant $(8 \pm 1 \mathrm{wt} \%)$ over the full range of depletion in basaltic components, from lherzolite to dunite, as $\mathrm{Al}_{2} \mathrm{O}_{3}$ contents drop from ca $4 \%$ to zero; $\mathrm{Cr}_{2} \mathrm{O}_{3}$ contents either remain constant (ca 0.4 wt \%) or rise with increasing degree of depletion. In Archean xenolith suites, depleted peridotites with $<2-1.5 \% \quad \mathrm{Al}_{2} \mathrm{O}_{3}$ have lower $\mathrm{FeO}$ (mean 6.5 wt \%) and $\mathrm{Cr}_{2} \mathrm{O}_{3}$ (mean 0.3-0.35 wt \%) contents than Phanerozoic peridotites. Weak positive correlations of $\mathrm{FeO}$ and $\mathrm{Cr}_{2} \mathrm{O}_{3}$ with $\mathrm{Al}_{2} \mathrm{O}_{3}$ suggest that high degrees of depletion reflect unbuffered melting, with neither garnet nor spinel on the liquidus. It has been suggested (e.g., Keleman et al., 1998) that the low FeO of Archean peridotites reflects the metasomatic introduction of orthopyroxene. However, the high opx/olivine once considered typical of Archean peridotites is relatively rare outside the SW Kaapvaal craton, while the low $\mathrm{FeO}$ contents are common to most Archean suites worldwide. Furthermore, low $\mathrm{FeO}$ contents are characteristic of Archean dunites as well as harzburgites and lherzolites.

Some studies (see Canil, 2004; references therein) have compared the compositions of Archean mantle samples with the products of experimental melting studies, and concluded that the SCLM peridotites are the product of low-P melting. However, these interpretations must be treated cautiously, simply because their basic assump- tion is that the xenoliths in question are the residues of a single melting process. It is now becoming clear that most of the "typical" Archean xenolith suites are dominated by repeatedly metasomatised samples (e.g., Simon et al., 2004; Bell et al., 2005). This is apparent from the presence of several modal percent clinopyroxene and gar-

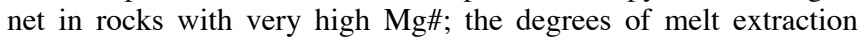
required to produce the high $\mathrm{Mg \#}$ would have eliminated cpx and garnet from the residues. Such metasomatism can have major effects on major- and trace-element compositions, including elements commonly regarded as compatible or refractory (e.g., van Achterbergh et al., 2001, references therein). Thomassot et al. (2006) have noted that the presence of methane-rich fluids (the precursors to diamonds) in the lithosphere could lead to strongly reducing conditions, which would enhance the mobility of normally refractory multivalent elements such as $\mathrm{Cr}$.

These observations suggest that the "original" Archean SCLM may have been a highly depleted material, ranging from dunite to harzburgite. In an illustrative example from western Norway, large massifs of such highly depleted rocks enclose limited zones of garnet lherzolite, often interbanded with eclogite and garnet pyroxenites. Whole-rock Re-Os dating shows that the dunites/harzburgites are Archean in age, while in-situ dating of individual sulfide grains in the lherzolites gives dominantly Proterozoic ages and some relict Archean ages (Beyer et al., 2004). The lherzolitic rocks show a compositional spectrum similar to that of typical cratonic xenolith suites (Figure 2). They are interpreted as zones of Proterozoic refertilisation, where the Archean dunite/harzburgite has been intruded and metasomatised by fluids derived from mafic magmas (now eclogites and pyroxenites; Beyer et al., 2006); Archean Re-Os ages have been partially overprinted by the introduction of Proterozoic sulfides during this metasomatism. If the metasomatic lherzolites are compared with the products of experimental melting studies, they would appear to be the products of relatively low-P melting, in clear conflict with their field and age relationships. However, the dunites/ harzburgites, which may provide an analogue for the original Archean SCLM in general, are consistent with high-degree melting at 3-5 GPa (Beyer et al., 2006).

Another test of the subduction model may be provided by comparisons with previously subducted oceanic slabs preserved in ophiolites. Serpentinisation is a ubiquitous feature of sea-floor peridotites, including those exposed in ophiolite sequences. Scambelluri et al. (2004) have followed the metamorphic evolution of serpentinised oceanic peridotites in ophiolites of the Ligurian Alps, up to the reactions that ultimately produce the anhydrous olivine+opx+spinel

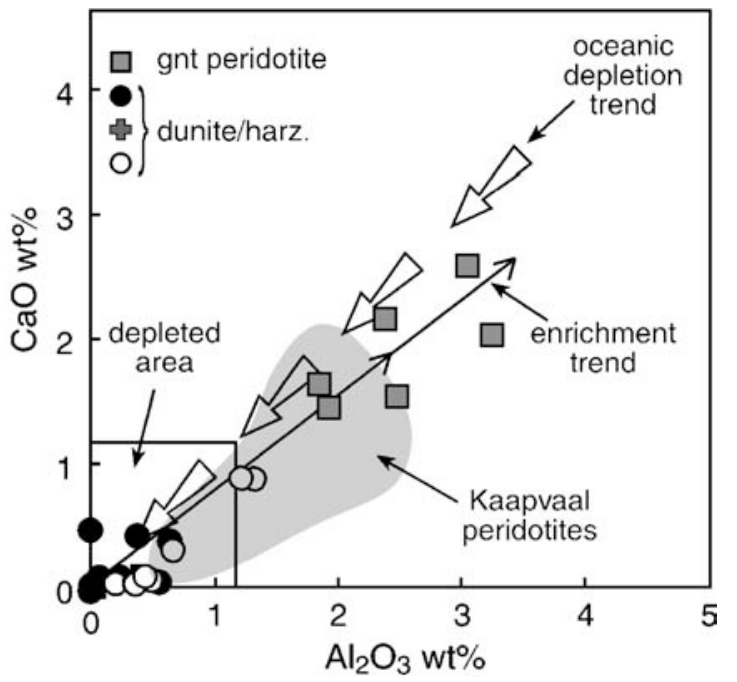

Figure 2 Generation of Proterozoic garnet lherzolites by refertilisation of Archean dunites/harzburgites in western Norway (after Beyer et al., 2006). Similar refertilisation, induced by the introduction of mafic melts (now eclogites and garnet pyroxenites) may have affected much of the Archean SCLM. 


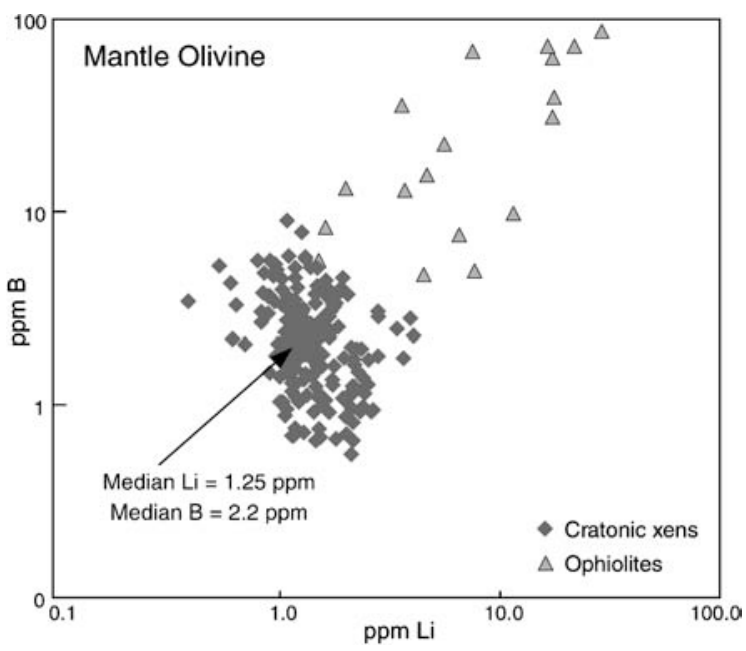

Figure 3 Li and B contents (measured by LAM-ICPMS) in olivine of peridotite xenoliths from South Africa and Siberia ("cratonic xens"); authors' unpublished data, available on request. Olivine in high-pressure subducted ophiolitic peridotites (Ligurian Alps; Scambelluri et al., 2004) retains high Li and B contents, a signature that has not been observed thus far in SCLM peridotites.

assemblage; after this stage the peridotite would experience no further dewatering reactions as it was subducted further into the mantle. A key finding of this work is that the highest-grade metamorphic olivine carries high levels of $\mathrm{Li}$ and $\mathrm{B}$ (a signature of the original serpentinisation) into the mantle. If SCLM peridotites have had a similar history of low-P melting, followed by serpentinisation and then by subduction, we might expect them to display similar high $\mathrm{Li}$ and $\mathrm{B}$ contents. However, a limited sample (Figure 3) suggests that this signature is not present in cratonic peridotites. Similarly, Woodland et al. (2002) found high $\mathrm{Li}$ contents in the cpx of clearly metabasaltic eclogites from high-P terrains, but low Li contents in the cpx of cratonic eclogite xenoliths and garnet pyroxenites; they concluded that the latter rocks represent high-P cumulates from melts intruding the SCLM.

\section{Eclogite distribution in the SCLM}

In the following discussion, xenolithic eclogites have been classified as Type 1 or Type 2 using mineral chemistry (McCandless and Gurney, 1986): in Type 1, garnets contain $\geq 0.09 \% \mathrm{Na}_{2} \mathrm{O}$ (cpx typically $\geq 0.08 \% \mathrm{~K}_{2} \mathrm{O}$ ); in Type 2 , garnets contain $<0.09 \% \mathrm{Na}_{2} \mathrm{O}$ (cpx typically $<0.08 \% \mathrm{~K}_{2} \mathrm{O}$ ). This scheme is broadly consistent with the original definition of these groups by MacGregor and Carter (1970), based on (commonly ambiguous) microstructural criteria in the xenolith suite from the Roberts Victor Mine (South Africa).

Equilibration temperatures can be calculated for eclogites using the distribution of $\mathrm{Fe}$ and $\mathrm{Mg}$ between cpx and gnt, but the mineral assemblage does not allow a direct calculation of pressure (depth). Therefore, in most studies of eclogite suites, a single $\mathrm{P}$ is assumed, resulting in a range of temperature that suggests a wide distribution of the eclogites in the SCLM (e.g., Jacob, 2004), but this simple approach may provide a misleading picture. The commonly used cpx-gnt thermometers (Ellis and Green, 1979; Krogh, 1988) are also dependent on both pressure and phase composition (e.g., Ca in garnet), and solution of the algorithm for a range of pressures generates a line in P-T space. It is reasonable to assume that the peridotites and the eclogites from each xenolith suite have both equilibrated to the same geotherm, which can be estimated by applying conventional geothermobarometric techniques to the garnet peridotite xenoliths. In this case, the intersection between the peridotite-derived geotherm and the P-T line generated for each eclogite xenolith can be used to estimate the depth of origin for that eclogite (Figure 4). In the following discussion we have taken a fixed uncertainty of $\pm 10 \mathrm{~km}$ on these depth estimates.

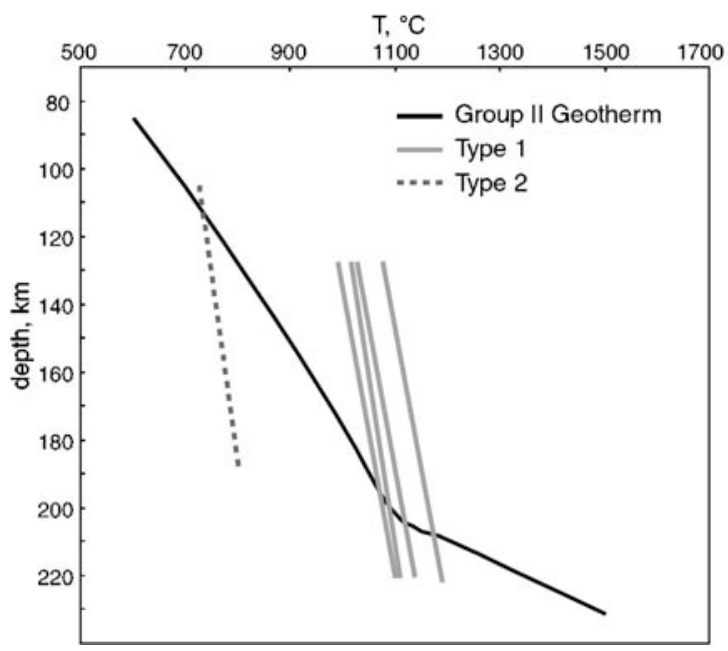

Figure 4 Estimation of depth for eclogite xenoliths (example: Bellsbank; see Figure 6). Solid line represents a geotherm for Group II kimberlites in the SW Kaapvaal craton, estimated from xenolith and xenocryst data (Griffin et al., 2003). Dashed lines represent the locus of $T$ estimates (Ellis and Green, 1979) for representative individual eclogite xenoliths; the intersection of these lines with the geotherm yields a depth estimate for each eclogite.

In Figure 5, the depth distribution of eclogites from the Roberts Victor Mine (South Africa) is compared with a Chemical Tomography section from the same kimberlite, derived from the analysis of peridotitic garnets in heavy mineral concentrates (for a detailed discussion of the construction of these sections, see O'Reilly and Griffin, 2006). This section shows the distribution with depth of differ-

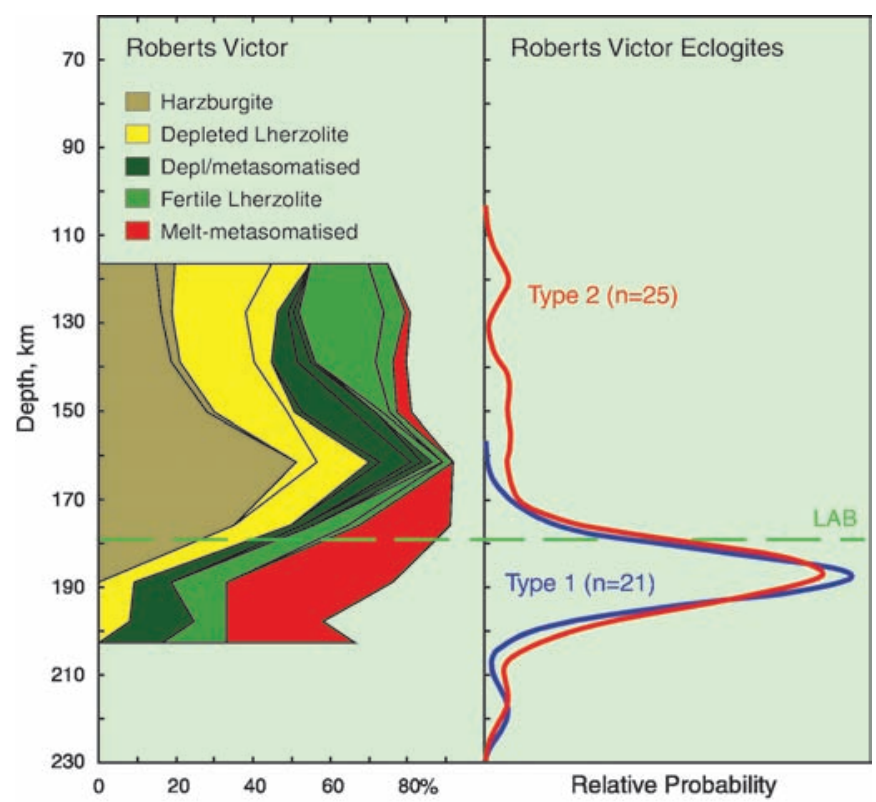

Figure 5 Distribution of eclogites in the SCLM beneath the Roberts Victor kimberlite, South Africa. The Chemical Tomography section (left; Griffin et al., 2003; 175 peridotitic garnets) shows a strongly depleted SCLM extending to ca $180 \mathrm{~km}$ depth (the LAB). Cumulative-probability histograms, calculated assuming a $\pm 10-k m$ uncertainty on each $P$ estimate, show that the eclogites are concentrated at $190 \pm 10 \mathrm{~km}$ depth, just below the LAB. Eclogite mineral-chemistry data from Carswell et al. (1981); Lappin, (1978); Sautter and Harte (1988); Gurney et al. (1984); MacGregor and Manton (1986); Schulze et al. (2000). 
ent (garnet-bearing) ultramafic rock types and metasomatic processes in the SCLM. A nominal "lithosphere-asthenosphere boundary" (LAB) is defined chemically, as the lower limit of abundant garnets with $<10 \mathrm{ppm} \mathrm{Y}$ (the mean value for peridotitic garnets; Griffin and Ryan, 1995; O'Reilly and Griffin, 2006), and is reflected in the distribution of "harzburgite" and "depleted lherzolite" rock types in the sections.

Both Type 1 and Type 2 eclogites from Roberts Victor are strongly concentrated in a layer $10-15 \mathrm{~km}$ thick just below the LAB (ca 180-195 km depth); the thickness of this layer is comparable to the estimated uncertainties $( \pm 10 \mathrm{~km})$ in the depth estimates. This result suggests that the higher $\mathrm{Na}$ in garnet, and $\mathrm{K}$ in cpx, of the Type 1 eclogites is a bulk-composition effect, and is not related to differences in depth of crystallisation. A small proportion (3/25) of Type 2 eclogites is scattered higher in the section. A similar situation is seen in the Bellsbank/Bobbejahn kimberlites (Figure 6); the LAB in this area is somewhat deeper ( $c a 200 \mathrm{~km}$ ), and the eclogites are concentrated in a $10-15 \mathrm{~km}$ layer at its base. In both cases the eclogite layer is spatially associated with a zone of strong melt-related metasomatism (characterised by the introduction of $\mathrm{Fe}, \mathrm{Ca}, \mathrm{Ti}$ and $\mathrm{Zr}$ ) in the peridotites near the LAB.

Roberts Victor and Bellsbank are Group II kimberlites, 120-125 Ma in age; the Group I kimberlites in this area are typically $\leq 100$ Ma old. Between the intrusion of these two groups of kimberlites, the SCLM underwent an episode of thinning, refertilisation and heating (Griffin et al., 2003; references therein). Thus a composite Chemical Tomography section for the SCLM sampled by Group I kimberlites in the SW Kaapvaal craton (Figure 7) is thinner, less depleted and more metasomatised, with the LAB at $c a 165 \mathrm{~km}$, instead of the $c a 200-\mathrm{km}$ depth recorded in the older Group II kimberlites. The eclogite suite from the Kaalvallei Group I kimberlite shows a strong clustering of the Type 1 , and most Type 2, eclogites near the shallower LAB, associated with a zone of intense meltrelated metasomatism. Another population of Type 2 eclogites occurs higher in the section, along with some melt-related metasomatism in the adjacent peridotites.

In northern Botswana, on the margin of the Kaapvaal craton, eclogites have been described from the Cretaceous Orapa and Letl-

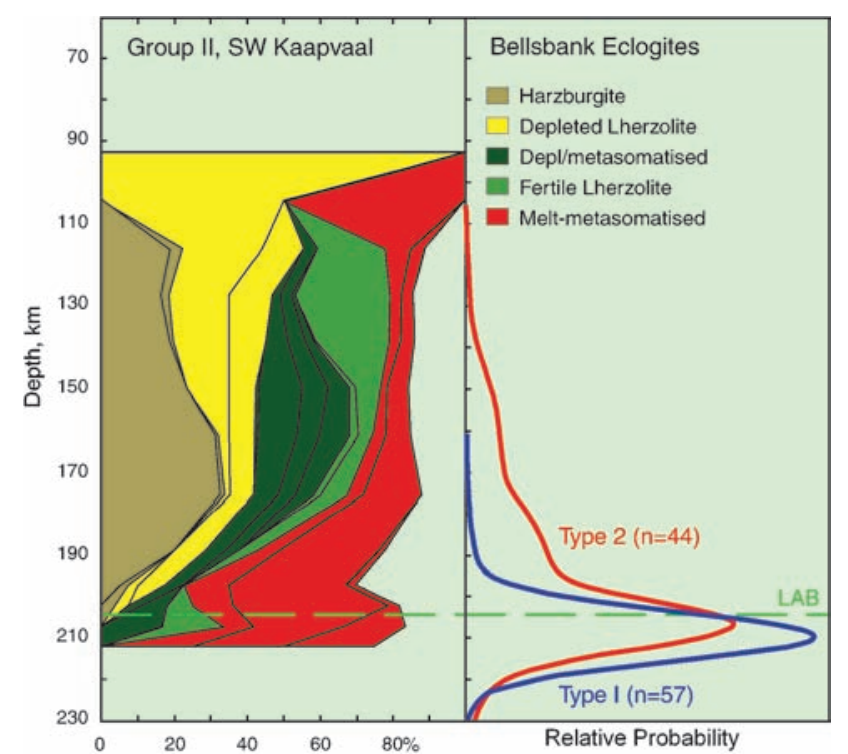

Figure 6 Distribution of eclogites in the SCLM beneath the Bellsbank kimberlite, South Africa. A combined Chemical Tomography section for Group II kimberlites in this area (left; Griffin et al., 2003; 360 peridotitic garnets) shows a strongly depleted SCLM extending to ca $200 \mathrm{~km}$ depth (the LAB). Eclogites are concentrated at $210 \pm 10 \mathrm{~km}$ depth, just below the LAB. Eclogite mineral-chemistry data from Smyth and Caporuschio (1984); Viljoen (1995); Carswell et al. (1981); Shervais et al. (1988).

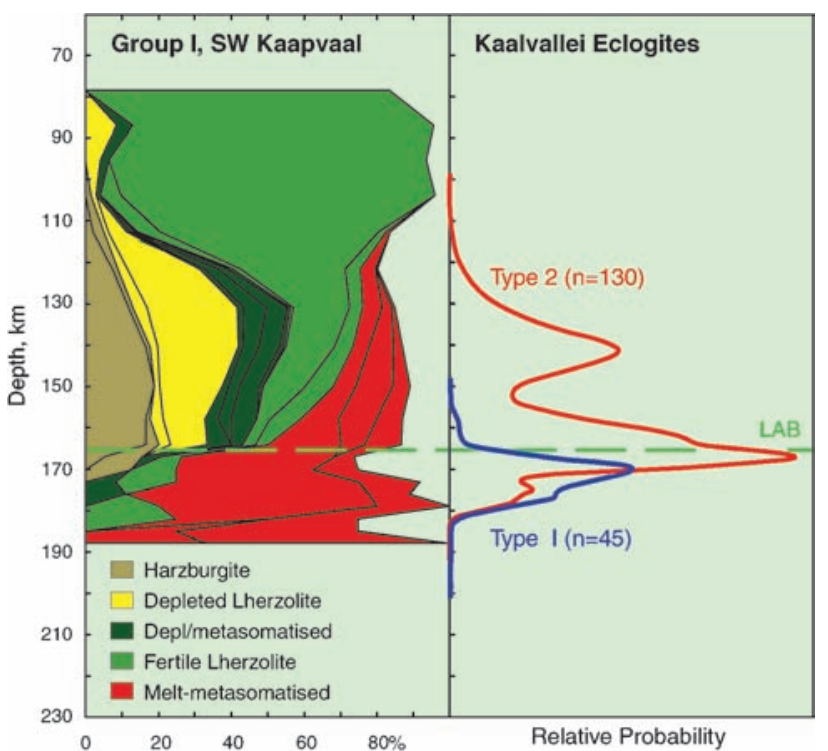

Figure 7 Distribution of eclogites in the SCLM beneath the Kaalvallei kimberlite, South Africa. A combined Chemical Tomography section for Group I kimberlites in this area (left; Griffin et al., 2003; 640 peridotitic garnets) shows a strongly modified SCLM extending to ca $165 \mathrm{~km}$ depth (the LAB). Cumulative-probability histograms show that Type 1, and most Type 2, eclogites are concentrated near the LAB; a second population of Type 2 eclogites is concentrated near $140 \mathrm{~km}$ depth. The distribution of the eclogites parallels the distribution of meltrelated metasomatic signatures in the peridotitic garnets. Eclogite mineral-chemistry data from Viljoen et al. (2005).

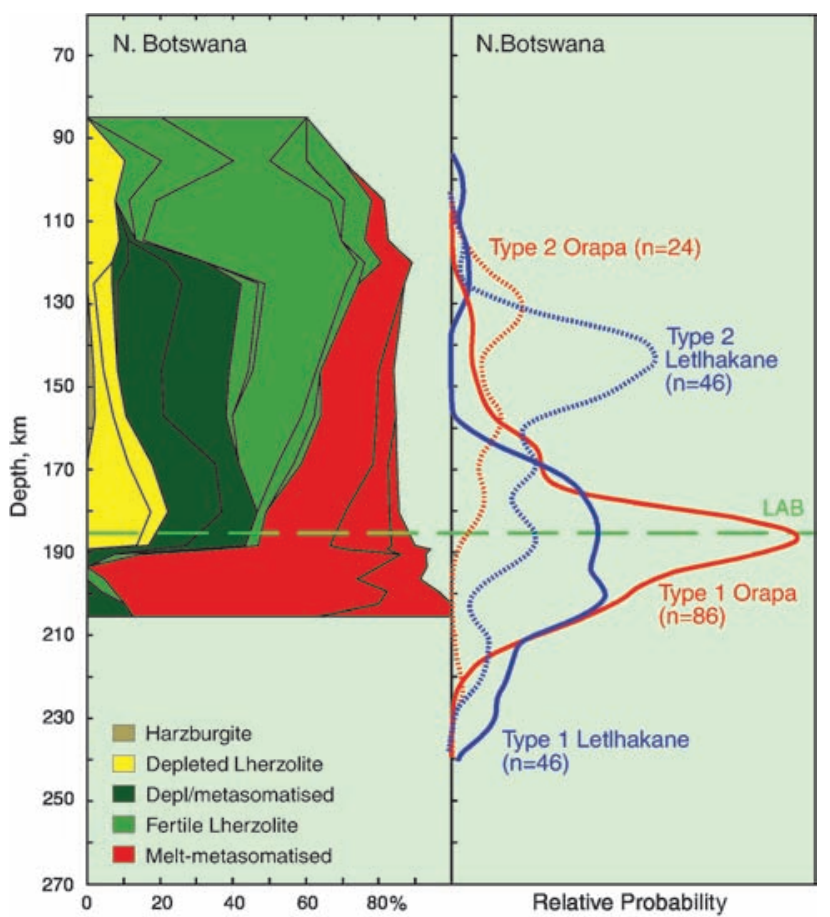

Figure 8 Distribution of eclogites in the SCLM beneath northern Botswana. A combined Chemical Tomography section for this area (left; Griffin et al., 2003; 390 peridotitic garnets) shows a strongly modified SCLM extending to ca $185 \mathrm{~km}$ depth (the LAB). Type 1 eclogites from Orapa and Letlhakane are concentrated around the $L A B$, while Type 2 eclogites from both pipes are spread more widely, from ca 120-160 km. Eclogite mineral-chemistry data from Shee (1978) and Stiefenhofer (1993). 


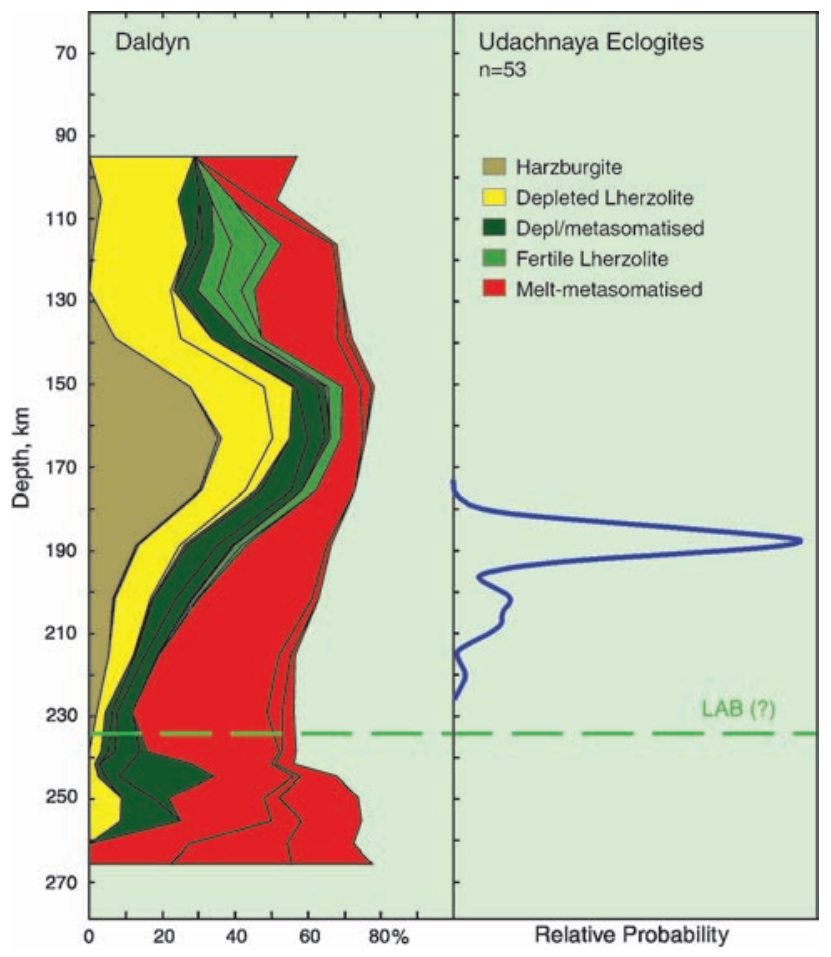

Figure 9 Distribution of eclogites in the SCLM beneath the Udachnaya kimberlite, Yakutia. A Chemical Tomography section for the Daldyn field (left; Griffin et al., 1999b; 850 peridotitic garnets) shows a strongly depleted layer between 150-180 km depth. The LAB may lie at the base of this layer, but Y-depleted garnets extend to at least $230 \mathrm{~km}$ depth. Cumulative-probability histograms show that the eclogites are concentrated at $185 \pm 5 \mathrm{~km}$ depth, just below the harzburgite-rich layer, with a tail to greater depth. Eclogite mineral-chemistry data from Sobolev et al. (1994); Jacob et al. (1994); Snyder et al. (1997).

hakane kimberlites. The Chemical Tomography section (Figure 8) shows few strongly depleted rocks, a high degree of metasomatism throughout the section, and a sharply defined LAB near $190 \mathrm{~km}$ depth. Type 1 eclogites from both pipes cluster around the LAB, though in much broader zones ( $c a$ 30-40 km thick) than seen in the previous examples. Type 2 eclogites, in contrast, tend to be concentrated at much shallower depth $(120-150 \mathrm{~km})$.

In the Udachnaya kimberlite (Yakutia), the Chemical Tomography section (Figure 9) shows a well-defined zone of highly depleted harzburgites and lherzolites from 150-180 km depth. Below this depleted layer the section shows increasing levels of melt-related metasomatism with depth, but Y-depleted garnets persist to $c a 235 \mathrm{~km}$ depth. The eclogites in this pipe are strongly concentrated just below the strongly depleted layer, with a tail to greater depths.

The depth distribution of eclogites in these sections is difficult to reconcile with the predictions of the subduction-stacking model (Figure 1). The possible exception is the example from northern Botswana, but a subduction model would have to explain the separation of the two types of eclogite by depth, a feature not seen in the other sections. It therefore is relevant to examine the commonly cited lines of evidence for a shallow (subduction) origin for cratonic eclogites.

\section{Cratonic Eclogites - an ocean-floor origin?}

\section{Stable-isotope fractionation}

The most widely accepted evidence for an ocean-floor origin for cratonic eclogites is the wide range of variation in carbon and oxygen isotopes seen in individual xenolith suites (Figure 10). Some suites show ranges in $\delta^{18} \mathrm{O}$ around the "mantle" value that are smaller than those seen in ophiolitic rocks, and generally more biased to lighter values. It is commonly stated that such fractionations can only occur at low $\mathrm{T}$, and must be related to the alteration of the basaltic protoliths of the eclogites, by circulation of sea water to different depths in the oceanic crust.

However, recent in-situ studies of the Mg-isotope systematics of olivine and other phases in high-T (ca $1200{ }^{\circ} \mathrm{C}$ ) peridotites (Pearson et al., 2006) have demonstrated variations of $\delta^{26} \mathrm{Mg}$ of $1-2$ permil in single samples, and 2-3 permil within a small suite. The relationships of these isotopic variations to microstructure and mineral composition suggest that the variations reflect kinetic fractionation during diffusion of $\mathrm{Mg}$ between the rock and a percolating melt. Similarly, a suite of spinel peridotites from SE Australia shows a range in $\delta^{26} \mathrm{Mg}$ of $>3$ permil, reflecting the metasomatic refertilisation of a depleted protolith, at $900-1000^{\circ} \mathrm{C}$. The $\delta^{26} \mathrm{Mg}$ fractionations observed thus far are comparable in magnitude to the $\delta^{18} \mathrm{O}$ variations in many eclogite suites (Figure 10), though smaller than the widest ranges. However, similar processes would produce larger fractionations in isotopically lighter elements. It is apparent, even from these limited data, that the fractionation of light stable isotopes is not a phenomenon limited to low temperatures.

Carbon (diamond and graphite) in cratonic eclogites is commonly (but not always; see Figure 11) isotopically light, extending to $\delta^{13} \mathrm{C}<-35$ permil relative to SMOW, compared to the mantle average $\left(\delta^{13} \mathrm{C} \approx-5\right.$ permil). This fractionation has been widely regarded as reflecting a biological, or at least low-T, origin for the carbon in these rocks, and hence as evidence for a subducted origin. This interpretation is difficult to accept, as $\mathrm{N}$-isotope data on diamonds are not compatible with a biogenic origin; since $\mathrm{N}$ and $\mathrm{C}$ would be strongly coupled in organic matter, the $\mathrm{N}$-isotope data argue strongly

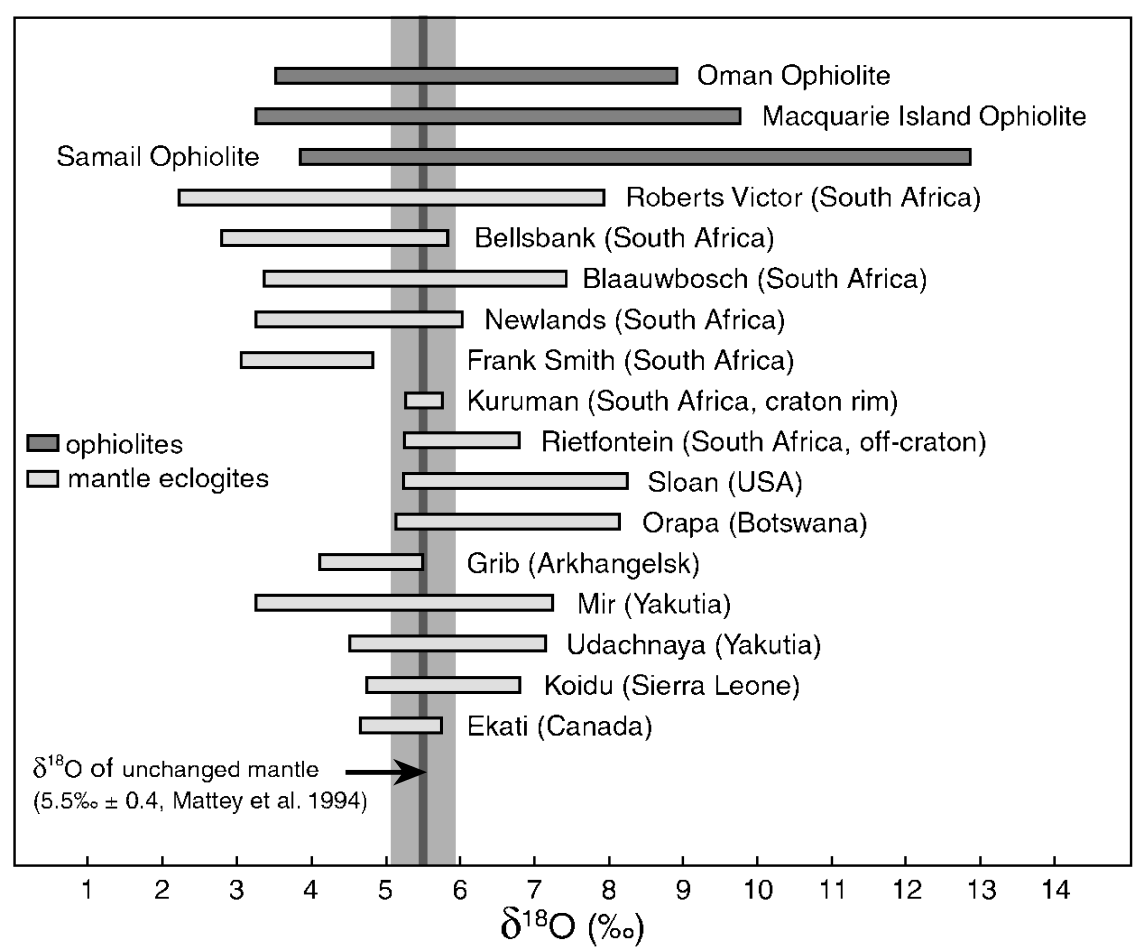

Figure 10 Ranges of $\delta^{18} \mathrm{O}$ in cratonic eclogites and ophiolites (after Jacob et al., 2004). 


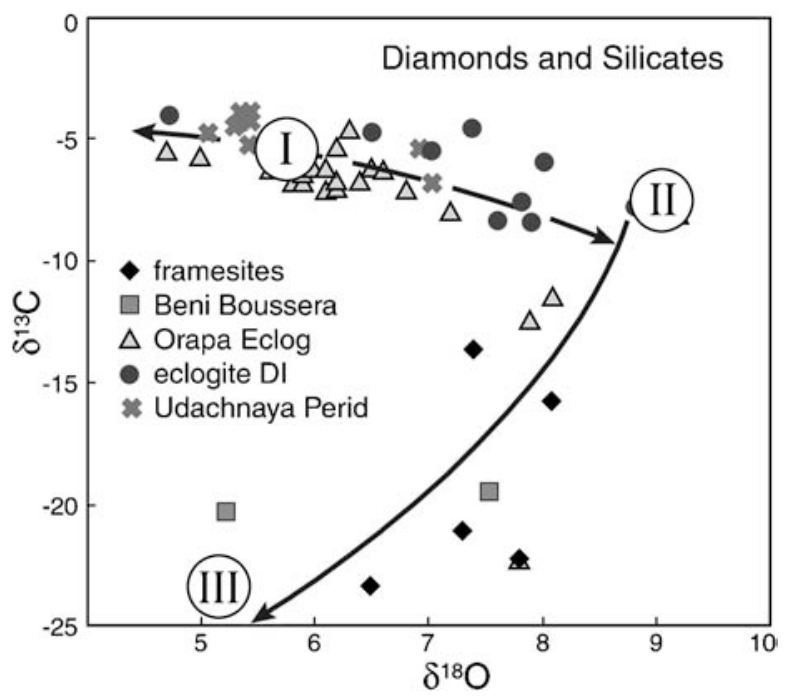

Figure $11 \delta^{13} \mathrm{C}$ of diamonds (or graphite pseudomorphs after diamond: Beni Bousera), vs $\delta^{18} O$ in coexisting silicates (as host rocks, inclusions in diamond, or syngenetically intergrown with diamond in framesites). Data sources: Pearson et al. (1991, 1993); Deines et al. (1991); Lowry et al. (1999); Snyder et al. (1995); Jacob et al. $(1994,2000)$.

against a subducted biogenic origin for the carbon (Cartigny et al., 1998a,b).

However, the isotopic fractionation of $\mathrm{C}$ observed in diamonds can be modelled as the result of Rayleigh fractionation processes during the oxidation of a methane-rich fluid to yield $\mathrm{C}+\mathrm{CO}_{2}+\mathrm{H}_{2} \mathrm{O}$ (Cartigny et al., 1998a; Maruoka et al., 2004). McCammon and Kopylova (2003), using similar models, emphasised that this process would be especially effective in eclogites. The wide variation of carbon and nitrogen isotope compositions within single diamonds (e.g., Bulanova et al., 2002) and between individual diamonds in single eclogitic or peridotitic xenoliths (e.g., Thomassot et al., 2006) also strongly suggest that the isotopic fractionations are related to processes in the fluids from which diamonds precipitated, rather than being a relic of processes in the oceanic crust.

Published data for the $\delta^{13} \mathrm{C}$ of diamonds and the $\delta^{18} \mathrm{O}$ of their coexisting silicate phases may provide a link between the isotopic fractionation of these two elements. Most of the data lie along two distinct trends (Figure 11). One, including data on diamondiferous peridotites from Udachnaya, diamondiferous eclogites from Orapa, and eclogite-paragenesis diamonds worldwide, extends from a mantle-like value $\left(\mathrm{I} ; \delta^{13} \mathrm{C} \approx-5, \delta^{18} \mathrm{O} \approx 4.5\right.$ ) toward a component (II) with heavier oxygen $\left(\delta^{18} \mathrm{O} \approx 9\right)$ and lighter carbon $\left(\delta^{13} \mathrm{C} \approx-6\right.$ to -8$)$. A second trend, which includes Orapa eclogites, African framesites and graphite psuedomorphs after diamond in a pyroxenite dike in the Beni Bousera peridotite massif, extends from component II toward much lighter carbon $\left(\delta^{13} \mathrm{C} \approx-24\right)$ and lighter oxygen (component III). The framesite data are especially interesting, because of compelling microstructural evidence that the diamond and its silicate inclusions are truly syngenetic (Dubosi and Kurat, 2002), which can be questioned in most other samples. If the range of low $\delta^{13} \mathrm{C}$ in framesites can be produced by redox-related Rayleigh fractionation (Cartigny et al., 1998a; Maruoka et al., 2004; McCammon and Kopylova, 2003), trend II-III suggests that this process fractionates $\mathrm{O}$ isotopes as well as $\mathrm{C}$ isotopes.

Trend I-II appears to be a mixing line between "normal mantle" and component II, and covers most of the range of $\delta^{18} \mathrm{O}$ seen in eclogite suites (Figure 10). Component II is isotopically similar to many mantle-derived carbonatites (Deines, 1989; cf Jacob et al., 2000), including some examples from oceanic settings (e.g., Kerguelen Plateau; Ray et al., 1999). The mixing line therefore may reflect the interaction of asthenosphere- derived carbonatitic fluids with the SCLM. Recent data on the traceelement compositions of diamonds (Rege et al., 2005, 2006; cf Dobosi and Kurat, 2002) indicate that framesites and most fibrous diamonds crystallise from fluids in the carbonate-kimberlite spectrum. The combination of fluid metasomatism and redox processes therefore may be sufficient to produce the stable-isotope fractionations observed in cratonic eclogite suites, without recourse to low-T processes.

\section{Europium anomalies}

Europium anomalies (relative to $\mathrm{Sm}$ and $\mathrm{Gd}$ ) have been reported from a number of eclogites, in either garnet or cpx, or occasionally both phases. In many cases these "anomalies" are an artefact due to a break in the slope of the chondrite-normalised REE pattern at Eu, but others are more convincing. Positive anomalies typically are interpreted as evidence of plagioclase accumulation, and negative ones as evidence of plagioclase subtraction; in both cases the implication is that the protoliths of the eclogites underwent magmatic fractionation at shallow depths, where plagioclase was stable.

However, the production of a Eu anomaly in a mineral (or rock) may also result from the interplay between crystal chemistry and redox conditions during metasomatism. McCammon et al. (2001) documented marked changes in redox state during the metasomatic conversion of harzburgite to garnet lherzolite, which could affect the
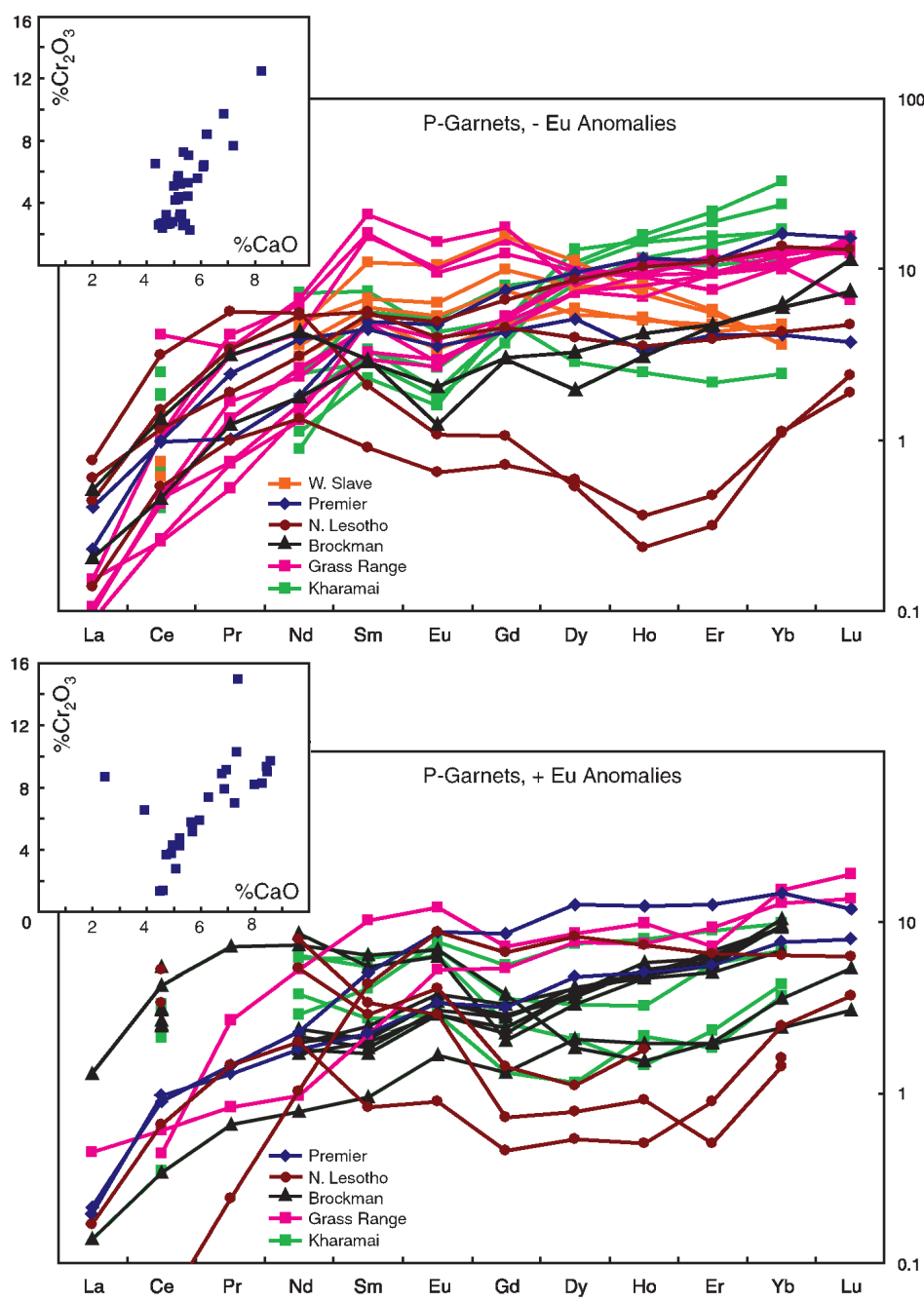

Figure $12 \mathrm{Eu}$ anomalies in chrome-pyrope garnets from kimberlites; these grains are derived from depleted peridotites in which plagioclase is unlikely to be stable at any conditions. Insets show range of $\mathrm{Ca}$ and $\mathrm{Cr}$ contents in the illustrated garnets. 
distribution of Eu relative to other REE. Taylor et al. (2000) analysed cpx inclusions in 30 diamonds from a single eclogite xenolith from Udachnaya, and found that some grains showed marked positive Eu anomalies, while others, even from the same diamond, showed none. A Eu anomaly inherited from a plagioclase-bearing protolith would presumably be present throughout the rock, so this pattern suggests to us that local redox processes were responsible for rapid spatial and temporal changes in $\mathrm{Eu}^{2+} / \mathrm{Eu}^{3+}$.

Other indirect evidence that this is an important phenomenon in the mantle lies in the REE patterns of Cr-pyrope garnets, derived from depleted, refractory peridotites in which plagioclase is unlikely to have been stable at any conditions. Eu anomalies, both positive and negative, are relatively common in peridotitic garnets (1-3\% of ca 6000 garnets analysed in this laboratory); examples are shown in Figure 12. These data have been collected by in-situ, time-resolved LAM-ICPMS analysis, and the anomalies clearly do not reflect the presence of inclusions of REE-bearing minerals. We interpret most, if not all, of these garnets as metasomatic phases introduced into previously more depleted peridotites (see discussion above, and Malkovets et al., 2007). While the details of these metasomatic processes are not yet fully understood, it is apparent that the presence of $\mathrm{Eu}$ anomalies in some eclogitic minerals (or whole rocks) is not in itself evidence of a shallow origin, or of later subduction.

\section{Bulk compositions: an alternative origin}

Most cratonic eclogite xenoliths, as might be expected from their bimineralic nature, are broadly basaltic to picritic in composition. However, they typically differ noticeably from basalts and gabbros in oceanic settings, and from eclogites in ophiolite sequences (see detailed review by Jacob, 2004). The interpretation of the xenolith suites as subducted oceanic material then requires the assumption of additional processes; suggestions have included hypothetical ones such as sea-floor alteration and partial melting during subduction, and observable ones such as metasomatic infiltration by melts and other fluids, and reaction with the host kimberlite.

Detailed arguments about the specific effects of each of these processes are beyond the scope of this note. However, insights into the origins of cratonic eclogites may come from examining analogous rocks from younger, less complex off-craton settings. Alkalibasalt volcanoes in such settings commonly carry suites of spinel peridotite ( \pm rare garnet lherzolite) xenoliths, derived from depths of 30-60 km; xenolith-derived geotherms from these areas are typically elevated and strongly convex, reflecting advective heat transport by basaltic magmas that have underplated the crust (O'Reilly and Griffin, 1985; Cull et al., 1991; Xu et al. 1996; references therein).

Garnet pyroxenites and garnet websterites are rare but widespread components of these xenolith suites. Their microstructures demonstrate that they originated as aggregates of coarse-grained $(\mathrm{cm}$ to $\mathrm{dm}$ scale), high-Al clinopyroxene ( \pm spinel \pm garnet) similar to phases produced experimentally by high-T crystallisation of basaltic magmas (e.g., Wilkinson, 1974; Irving, 1974; Griffin et al., 1984; Keshav and Sen, 2004). On cooling, cpx exsolves garnet $\pm 0 p x \pm$ spinel \pm feldspar (and rare sapphirine; Griffin and O'Reilly, 1986); recrystallisation of the exsolved phases produces a granoblastic structure. These pyroxenites have therefore been widely interpreted as cumulates and crystallised melts, related to the underplating basaltic magmas. Similar rocks are found in many European peridotite massifs, where they occur as dikes and veins, commonly showing considerable reaction with the ultramafic wall rocks (e.g., Beni Boussera; Pearson et al., 1991, 1993).

Exsolution features similar to those in the Phanerozoic pyroxenites also are well-known, though less common, in cratonic eclog-

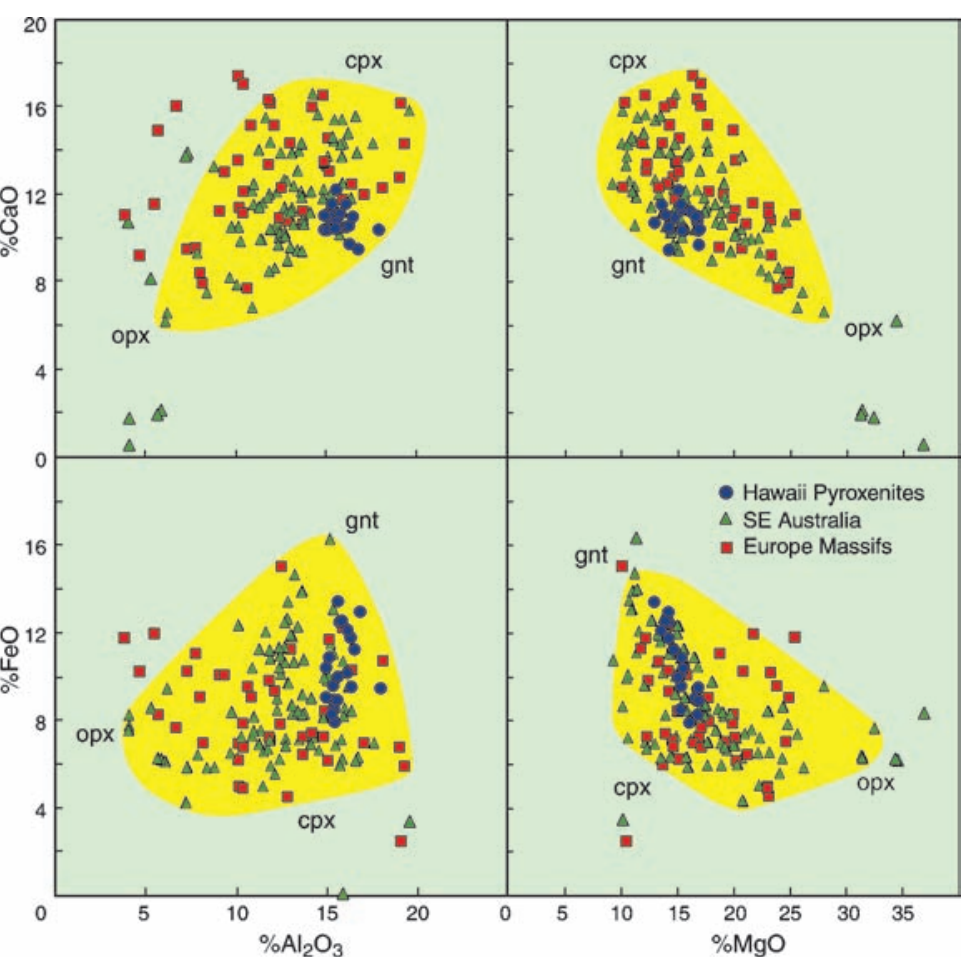

Figure 13 Whole-rock compositions for Phanerozoic garnet pyroxenite xenoliths in alkali basalts from SE Australia (Lovering and White, 1969; Griffin et al., 1984, unpubl. data) and Hawaii (Keshav and Sen, 2004), and pyroxenite dikes in European peridotite massifs (Bodinier et al., 1987; Kornprobst, 1969; Kornprobst and Conquere, 1972; Pearson et al., 1993; Suen and Frey, 1987). Shaded field encompasses most of the data.

ite suites (see reviews by Smyth et al., 1989; Jerde et al., 1993), and the exsolved phases include sanidine, kyanite, corundum and coesite. These microstructures have long been recognised as indicators of cooling of coarse-grained Al-rich pyroxenes from magmatic temperatures $\left(\mathrm{ca} 1400^{\circ} \mathrm{C}\right)$ to an ambient geotherm (Harte and Gurney, 1975; Lappin, 1978; Sautter and Harte, 1988). Spectacular examples of such exsolution microstructures recently have been described from eclogites in the Kuruman kimberlites of South Africa (Schminkler et al., 2005). These were interpreted as evidence of decompression, to be consistent with an inferred subduction origin, but also could simply reflect cooling from magmatic temperatures.

Are the Phanerozoic pyroxenites, with relatively clear origins, a possible analogue for the cratonic eclogites? Figure 13 shows some key compositional indicators, least likely to be strongly affected by metasomatism, for pyroxenite xenoliths from alkali basalts in SE Australia and Hawaii, and dikes and veins in European peridotite massifs. The similarities among these suites are obvious; some of the pyroxenites from peridotite massifs extend to lower $\mathrm{Al}_{2} \mathrm{O}_{3}$ contents (higher normative opx) than most of the xenoliths.

Bulk-compositional data for cratonic eclogite xenoliths are notoriously unreliable, because of the effects of alteration and infiltration by kimberlitic melts. Bulk compositions (at least for most major elements) can be calculated from modal data and mineral analyses (ignoring the effects of older metasomatism). However, modal analyses are also unreliable because in many specimens grain size is large relative to sample size, and large xenoliths may show pronounced compositional banding. In an attempt to circumvent this problem, we have calculated bulk compositions for samples from three cratonic eclogite suites, using mineral analyses and assuming gnt:cpx $=1$. The results (Figure 14) are consistent with the published range of whole-rock analyses of cratonic eclogites (Jacob, 2004); the overlap between the cratonic and Phanerozoic suites could be improved by adopting a slightly lower gnt:cpx ratio for the eclogites. These data demonstrate the compositional similarity between cratonic eclogites and the Phanerozoic pyroxenites. 


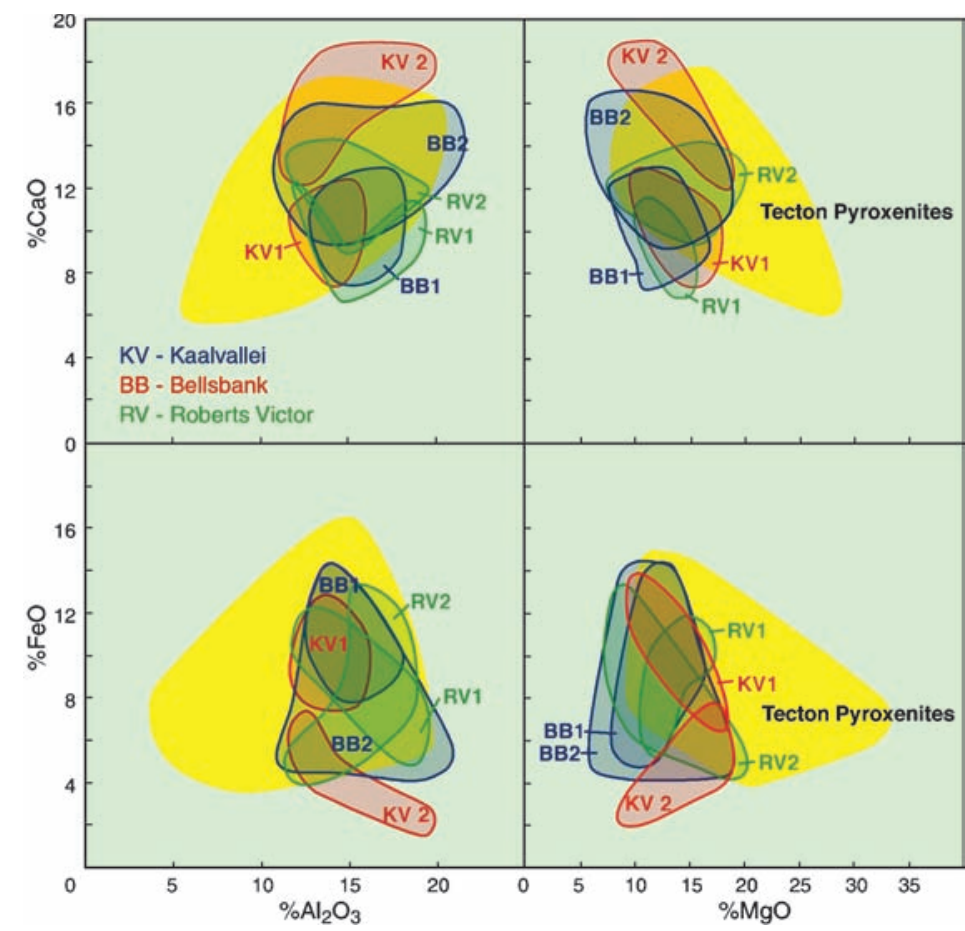

Figure 14 Compositions of cratonic eclogite suites, calculated from mineral chemistry assuming that gnt:cpx=1. Shaded fields, Phanerozoic garnet pyroxenite data from Figure 13. Data sources: see Figures 5-7. $R V$, Roberts Victor; BB, Bellsbank; KV, Kallvaalei.

\section{Discussion and conclusions}

The compositional analysis given above suggests that the Phanerozoic pyroxenites, found both as xenoliths and in peridotite massifs, are a good analogue for the cratonic eclogites. The microstructural and compositional features of these pyroxenites leave little doubt that they formed by intrusion of melts into the SCLM, producing cumulates and zones of reaction between melts and peridotitic wall rocks. As noted above, similar microstructures are found in cratonic eclogite xenoliths.

In the SCLM sections analysed here, Type 1 (and most Type 2) eclogites are strongly concentrated near the base of the depleted lithosphere. Type 2 eclogites may extend further up into the SCLM, notably in the section from northern Botswana. It might be argued that these eclogite-rich horizons represent layers of underthrust ocean floor. However, the distribution of eclogites in Group II and Group I kimberlites from the SW Kaapvaal craton makes this mechanism difficult to accept. In Group II time (>115 Ma) the eclogite layer is present at the base of a thick, cool and depleted SCLM (190-210 km), and there are few eclogites at shallower depth. A short time later, in Group I time (80-100 Ma), an eclogite layer is present at the base of a thinner ( $c a 165 \mathrm{~km})$, hotter and more metasomatised SCLM. To explain this coincidence, the Kaalvaalei eclogites would need to have been subducted beneath the craton 100-115 Ma ago. However, we are not aware of any plate reconstructions that would allow shallow subduction beneath the Kaapvaal craton in this time span.

The eclogites, especially Type 1 , are associated with zones of intense melt-related metasomatism in the adjacent peridotites, reflecting the introduction of $\mathrm{Fe}, \mathrm{Ti}, \mathrm{Ca}, \mathrm{Al}$ and $\mathrm{Zr}$ into the base of the depleted SCLM; this is the chemical signature produced by melt percolation in high-T sheared peridotites, which are derived from similar depths (Smith et al., 1993). We therefore feel it is more likely that the eclogites represent the ponding of asthenosphere-derived melts near the base of the depleted lithosphere (cf Gurney, 1990); these melts, and fluids expelled during their crystallisation, probably are responsible for the observed melt-related metasomatism at these depths. It seems probable that older generations of eclogites near the LAB also have been affected by metasomatism, further complicating the interpretation of their geochemistry. Several types of metasomatism, with different geochemical signatures, are recorded in peridotite xenoliths sampled from throughout the lithospheric mantle. These signatures reflect repeated thermal events and episodes of fluid transport throughout $>3 \mathrm{Ga}$ of history, and it is difficult to be sure that any peridotite, or eclogite, xenolith retains a pristine signature of its origin.

Re-Os model ages on eclogites, and "eclogitic" sulfides from diamonds, commonly give Archean ages, which have been interpreted as evidence of Archean subduction processes (e.g., Shirey et al., 2001). It would appear to be impossible to reconcile these ages with the suggested $<100 \mathrm{Ma}$ emplacement of the eclogites in the Group I kimberlites. However, Os is strongly concentrated in sulfide phases in the upper mantle (Alard et al., 2000; Powell and O'Reilly, 2007), and Spetsius et al. (2002) have demonstrated that even extreme mantle metasomatism, leading to the growth of zircon in peridotite, does not reset the Os model ages of high-Os sulfides. Since sulfide phases are also highly mobile in the upper mantle, ancient Os-isotopic signatures are easily imparted to younger intrusions or residues, as observed in abyssal peridotites (Alard et al., 2006). Examples of this process are given by Larsen (2003), who showed that Tertiary picrite lavas in west Greenland have inherited Archean Os model ages from the SCLM, and by Schaefer et al. (2002), who found Archean Os-isotope signatures in lavas from the Azores.

In most cases, the eclogites appear to be concentrated in a layer $10-15 \mathrm{~km}$ thick. If this layer consists of $30-50 \%$ eclogite, then the proportion of eclogite, averaged over a garnet-bearing SCLM 100-200 km thick (e.g., Figure 6) would be a few percent, consistent with the estimates of Schulze (1989). A layer of this composition would be significantly denser than the underlying asthenosphere, and susceptible to delamination; detailed modelling incorporating realistic rheology and estimates of external stresses would be required to evaluate its long-term stability.

The observation of significant $\mathrm{Mg}$-isotope fractionation by kinetic or diffusion processes at high $\mathrm{T}$ (Pearson et al., 2006) demonstrates that stable-isotope fractionation, relative to the "mantle" value, is not restricted to low T. Kinetic processes during redox reactions can explain the full range of $\delta^{13} \mathrm{C}$ fractionation observed in eclogite-related diamonds (Maruoka et al., 2005; McCammon and Kopylova, 2003). The broad correlations between $\delta^{13} \mathrm{C}$ of diamonds and $\delta^{18} \mathrm{O}$ of coexisting silicates (Figure 10) suggest that the full range of $\delta^{18} \mathrm{O}$ observed in eclogite xenoliths may be produced either by similar redox-related kinetic fractionation, or by mixing between (?carbonatitic) fluids and the lithospheric mantle. The interpretation of O-isotope fractionation in cratonic eclogites as evidence of low-T alteration must be regarded as ambiguous, and alternative interpretations should be seriously considered.

Europium anomalies occur in the garnets of depleted peridotites where plagioclase would not have been stable under any conditions. These anomalies await a detailed explanation; we suggest that they reflect the interplay between redox state and crystal chemistry during metasomatism by mantle-derived fluids. Similar metasomatic processes may have affected many eclogites, as well as the enclosing peridotites. In any case, the interpretation of Eu anomalies in eclogites as evidence of plagioclase fractionation requires supporting evidence.

Finally, the origins of cratonic eclogites and cratonic peridotites must be considered together, because most of a subducting slab consists of peridotite. By analogy with the Norwegian peridotites discussed above, we suggest that the primary protolith of most Archean SCLM consisted of highly depleted dunites and harzburgites. The major-element chemistry of these rocks is consistent with highdegree melting at 3-5 GPa (Beyer et al., 2006), and is distinctly different from that of depleted peridotites produced in modern oceanic environments (Griffin et al., 1998, 1999). The widely studied garnet lherzolite xenoliths in kimberlites probably represent the repeated 
metasomatic refertilisation of this dunite/harzburgite protolith, by fluids ranging from carbonatitic to basaltic, over $\mathrm{ca} 3 \mathrm{Ga}$ of residence in the cratonic roots. If the cratonic SCLM contains little subducted oceanic peridotite, it becomes difficult to see how the denser eclogitic part of the oceanic slab could be emplaced into, or remain in, the subcontinental lithosphere.

We conclude that, at present, there is no unambiguous evidence that SCLM eclogites represent subducted ocean-floor material, and there is strong evidence from eclogite distribution, composition and microstructure to support an origin as underplated magmas, cumulates and melt-peridotite reaction zones. This does not mean there is no subducted material in the cratonic SCLM, but less ambiguous data (perhaps to come from $\mathrm{Tl}$ isotope signatures; Nielsen et al., 2006) will be required to establish a more rigorous case. Even then, it may be difficult to distinguish between subducted ocean floor being added directly to the SCLM, and the intrusion of magmas derived from more deeply-subducted protoliths.

\section{Acknowledgements}

We thank Gautum Sen for supplying the Hawaiian data, Yigang Xu and Martin Menzies for the invitation to present this talk at IAVCEI, and Ken Ludwig for supplying the Isoplot software used for cumulative-probability plots. We have benefited from numerous discussions on this subject with Norm Pearson, Olivier Alard, Thomas Stachel and Catherine McCammon. Four anonymous referees provided useful comments; those which would have required a doubling of the paper's length have been saved for later. This work was supported by ARC Discovery grants. Analytical data were obtained using instrumentation funded by ARC LIEF, and DEST Systemic Infrastructure Grants and Macquarie University. This is publication number no. 461 from the ARC National Key Centre for Geochemical Evolution and Metallogeny of Continents (www.es.mq.edu.au/ GEMOC/).

\section{References}

Alard, O., Griffin, W.L., Lorand, J.P., Jackson, S.E. and O'Reilly, S.Y., 2000, Non-chondritic distribution of the highly siderophile elements in mantle sulfides: Nature 407, 891-894.

Alard, O., Gréau, Y., Godard, M., Griffin, W.L., Lorand, J.-P., Seyler, M., and O'Reilly, S.Y., 2006, Remobilisation of an old and depleted reservoir within the convective young oceanic mantle: Extended Abstract 16th Goldschmidt Conference, Melbourne.

Bell, D.R., Gregoire, M., Grove, T.L., Chatterjee, N., Carlson, R.W., and Buseck, P.R., 2005, Silica and volatile-element metasomatism of Archean mantle: a xenolith-scale example from the Kaapvaal Craton: Contributions to Mineralogy and Petrology 150, 251-267.

Beyer, E.E., Brueckner, H.K., Griffin W.L., O'Reilly, S.Y., and Graham, S., 2004, Archean mantle fragments in Proterozoic crust, Western Gneiss Region, Norway: Geology, 32(7): 609-612.

Beyer, E.E., Griffin W.L., and O'Reilly, S.Y., 2006, Transformation of Archean lithospheric mantle by refertilisation: evidence from exposed peridotites in the Western Gneiss Region, Norway: Journal of Petrology $47,1611-1636$.

Bodinier, J.J., Giraud, M., Fabries, J., Dostal, J., and Dupuy, C., 1987, Petrogenesis of layered pyroxenites from the Lherz, Frechinede and Prades ultramafic bodies (Ariege, French Pyrenees): Geochimica et Cosmochimica Acta 51, 279-290.

Bulanova, G.P., Pearson, D.G., Hauri, E.H., and Griffin, B.J., 2002, Carbon and nitrogen isotope systematics within a sector-growth diamond from the Mir kimberlite, Yakutia: Chemical Geology 188, 105-127.

Canil, D., 2004, Mildly incompatible elements in peridotites and the origins of mantle lithosphere: Lithos 77, 375-393.

Carswell, D.A., Dawson, J.B., and Gibb, F.G.F., 1981, Equilibration conditions of upper-mantle eclogites: implications for kyanite-bearing and diamondiferous varieties: Mineralogical Magazine 44,79-89.

Cartigny, P., Harris, J.W., Phillips, D., Boyd, S.R. and Javoy, M., 1998, Subduction-related diamonds? - The evidence for a mantle-derived origin from coupled $\delta^{13} \mathrm{C}-\delta^{15} \mathrm{~N}$ determinations: Chemical Geology 147 $147-159$

Cartigny, P., Harris, J.W., and Javoy, M., 1998, Eclogitic diamond formation at Jwaneng: No room for a recycled component: Science 280, 1421-1424.

Cooper, C.M., Lenardic, A., Levander, A. and Moresi, L., 2006, Creation and preservation of cratonic lithosphere: seismic constraints and geodynamic models: American Geophysical Union Monograph $164,75-88$.

Cull, J.P., O'Reilly, S.Y., and Griffin, W.L., 1991, Xenolith geotherms and crustal models in eastern Australia: Tectonophysics 192, 359-366.

Deines, P., 1999, Stable isotope variations in carbonatites, in Bell, K. (ed.) Carbonatites: Genesis and evolution: Wyllie, London, pp. 301-359.

Deines, P., Harris, J.W., Robinson, D.N., Gurney, J.J., and Shee, S.R., 1991, Carbon and oxygen isotope variations in diamond and graphite eclogites from Orapa, Botswana, and the nitrogen content of their diamonds: Geochimica et Cosmochimica Acta 55, 515-524.

Dobosi, G. and Kurat, G., 2002, Trace element abundances in garnets and clinopyroxenes from diamondites - a signature of carbonatitic fluid: Mineralogy and Petrology 76, 21-38.

Ellis, D.J. and Green, D.H., 1979, An experimental study of the effect of Ca upon garnet-clinopyroxene $\mathrm{Fe}-\mathrm{Mg}$ exchange equilibria: Contributions to Mineralogy and Petrology 73, 253-266.

Griffin, W.L., 1987, "On the eclogites of Norway" - 65 years later: Mineralogical Magazine 51, 333-343.

Griffin, W.L., Wass, S.Y. and Hollis, J.D., 1984, Ultramafic xenoliths from Bullenmerri and Gnotuk maars, Victoria, Australia: Petrology of a subcontinental crust-mantle transition: Journal of Petrology 25 , 53-87.

Griffin, W.L. and O'Reilly, S.Y., 1986, Mantle-derived sapphirine: Mineralogical Magazine 50,635-640.

Griffin, W.L. and Ryan, C.G., 1995, Trace elements in indicator minerals: Area selection and target evaluation in diamond exploration: Journal of Geochemical Exploration 53, 311-337.

Griffin, W.L., O'Reilly, S.Y., Ryan, C.G., Gaul, O. and Ionov, D., 1998, Secular variation in the composition of subcontinental lithospheric mantle, in J. Braun, J.C. Dooley, B.R. Goleby, R.D. van der Hilst and C.T. Klootwijk (Eds), Structure and Evolution of the Australian Continent: Geodynamics Volume 26, American Geopyhysical Union, Washington D.C. pp. 1-26.

Griffin, W.L., O'Reilly, S.Y., and Ryan, C.G., 1999, The composition and origin of subcontinental lithospheric mantle, in Y. Fei, C.M., Bertka and B.O. Mysen (Eds.), Mantle Petrology: Field observations and high-pressure experimentation, A tribute to Francis R. (Joe) Boyd: Geochemical Society Special Publication \#6, The Geochemical Society (Houston), pp. $13-45$

Griffin, W.L., Ryan, C.G., Kaminsky, F.V., O'Reilly, S.Y., Natapov, L.M. Win, T.T., Kinny, P.D., and Ilupin, I.P., 1999, The Siberian Lithosphere Traverse: Mantle terranes and the assembly of the Siberian Craton: Tectonophysics 310, 1-35.

Griffin, W.L., O'Reilly, S.Y., Natapov, L.M. and Ryan, C.G., 2003, The evolution of lithospheric mantle beneath the Kalahari Craton and its margins: Lithos 71, 215-241.

Gurney, J.J., 1990, The diamondiferous roots of our wandering continents: South Africa Journal of Geology 93, 424-437.

Gurney, J.J., Harris, J.W. and Rickard, R.S., 1984, Minerals associated with diamonds from the Roberts Victor mine, in J. Kornprobst (ed.), Kimberlites, II. The mantle and crust-mantle relationships: Elsevier, Amsterdam, 1984 , pp. 25-32

Hart, R.J., Tredoux, M., and de Wit, M.J., 1997, Refractory trace elements in diamond inclusions: further clues to the origins of the ancient cratons: Geology 25, 1143-1146.

Helmstedt, H.H. and Gurney, J.J., 1995, Geotectonic controls of primary diamond deposits: implications for area selection: Journal of Geochemical Exploration 53, 125-144.

Irving, A.J., 1974, Geochemical and high-pressure experimental studies of garnet pyroxenite and pyroxene granulite xenoliths from the Delegate basaltic pies, Australia: Journal of Petrology 15, 1-40.

Keshav, S. and Sen, G., 2004, The depth of magma fractionation in the oceanic mantle: insights from garnet-bearing xenoliths from Oahu, Hawaii: Geophysical Research Letters 3, doi: 10.1029/2003GL018990.

Jacob, D.E., 2004, Nature and origin of eclogite xenoliths in kimberlites: Lithos 77, 295-316. 
Jacob, D., Jagoutz, E., Lowry, D., Mattey, D., and Kudrjavtseva, G., 1994, Diamondiferous eclogites from Siberia: remnants of Archean oceanic crust: Geochimica Cosmochimica Acta 58, 5191-5207.

Jacob, D.E., Viljoen, K.S., Gassineau, N., and Jagoutz, E., 2000, Remobilization in the cratonic lithosphere recorded in polycrystalline diamond: Science 289, 1182-1185.

Jerde, E.A., Taylor, L.A., Crozaz, G., and Sobolev, N.V., 1993, Exsolution of garnet within clinopyroxene of mantle eclogites: major and trace-element geochemistry: Contributions to Mineralogy and Petrology 114, 148-159.

Kelemen, P.B., Hart, S.R. and Bernstein, S., 1998, Silica enrichment in the continental upper mantle via melt/rock reaction: Earth and Planetary Science Letters 164, 387-406.

Kornprobst, J., 1969, Le massif ultrabasique des Beni Bouchera (Rif Interne, Maroc): Etude des peridotites de haut temperature et de haute pression, et des pyroxenolites, a grenat ou sans grenat, qui leur sont associees: Contributions to Mineralogy and Petrology 23, 283-322.

Kornprobst, J. and Conquere, F., 1972, Les Pyroxenolites A Grenat Du Massif De Lherzolite De Moncaup (Haute Garoone - France); Caracteres Communs Avec Certaines Enclaves Des Basaltes Alcalins: Earth and Planetary Science Letters 16, 1-14.

Lappin, M., 1978, The evolution of a grospydite from the Robertws Victor Mine, South Africa: Contributions to Mineralogy and Petrology 66, 229-241.

Larsen, L.M., Pedersen, A.K., Sundvoll, B., and Frei, R. ,2003, Alkali picrites formed by melting of old metasomatised lithospheric mantle: Manitdlat Member, Vaigat Formation, Palaeocene of West Greenland: Journal of Petrology 44, 3-38.

Lovering, J.F. and White, A.J.R., 1969, Granulitic and eclogitic inclusions from basic pipes at Delegate, Australia: Contributions to Mineralogy and Petrology 21, 9-52.

Lowry, D., Mattey, D.P., and Harris, J.W., 1999, Oxygen isotope composition of syngenetic inclusions in diamond from the Finsch Mine, RSA: Geochimica et Cosmochimica Acta 63, 1825-1836.

McCammon, C.A., Griffin, W.L., Shee, S.H., and O'Neill, H.St.C., 2001, Oxidation during metasomatism in ultramafic xenoliths from the Wesselton kimberlite, South Africa: Contributions to Mineralogy and Petrology 141, 287-296.

McCammon, C.A. and Kopylova, M.G., 2003, Mantle oxygen fugacity and diamond formation: Extended Abstract 8th International Kimberlite Conference, Vancouver. FLA 0262.

McCandless, T.E. and Gurney J.J., 1986, Sodium in garnet and potassium in clinopyroxene: criteria for classifying mantle eclogites: Geological Society of Australia Special Publication 14, 827-832.

MacGregor, I.D. and Carter, J.L., 1970, The chemistry of clinopyroxenes and garnets of eclogite and peridotite xenoliths from the Roberts Victor mine, South Africa: Physics of the Earth and Planetary Interiors 3, 391-397.

MacGregor, I.D. and Manton, W.I., 1986, Roberts Victor Eclogites: Ancient oceanic crust: Journal of Geophysical Research 91, 14063-14079.

Malkovets, V.G., Griffin, W.L., O'Reilly, S.Y., and Wood, B.J., 2007, Diamond, subcalcic garnet and mantle metasomatism: Kimberlite sampling patterns define the link: Geology (in press).

Maruoka, T., Kurat, G., Dobosi, G., and Koeberl, C. ,2004, Isotopic composition of carbon in diamonds of diamondites: Record of mass fractionation in the upper mantle: Geochim. Cosmochim. Acta 68, 1635-1644.

Nielsen, S.G. Rehkamper, M., Norman, M.D., Halliday, A.N., and Harrison, D. 2006, Thallium isotopic evidence for ferromanganese sediments in the mantle source of Hawaiian basalts: Nature 439, 314-317.

O'Reilly, S.Y.and Griffin, W.L., 1985, A xenolith-derived geotherm for southeastern Australia and its geophysical implications: Tectonophysics $111,41-63$.

O'Reilly, S.Y. and Griffin, W.L., 2006, Imaging chemical and thermal heterogeneity in the sub-continental lithospheric mantle with garnets and xenoliths: Geophysical implications: Tectonophysics 416, 289-309.

Pearson, D.G., Davies, G.R., Nixon, P.H. and Mattey, D.P., 1991, A carbon isotope study of diamond facies pyroxenites and associated rocks from the Beni Bousera Peridotite, North Morocco: Journal of Petrology Special Volume 1991, 175-190.

Pearson, D.G., Davies, G.R., and Nixon, P.H., 1993, Geochemical constraints on the petrogenesis of diamond facies pyroxenites from the Beni Bousera peridotite massif, N. Morocco: Journal of Petrology 34, $125-172$.

Pearson, N.J., Griffin, W.L., Alard, O. and O'Reilly, S.Y., 2006, The isotopic composition of magnesium in mantle olivine: records of depletion and metasomatism: Chemical Geology 266, 115-133.
Poudjom Djomani, Y.H., O'Reilly, S.Y., Griffin, W.L., and Morgan, P., 2001, The density structure of subcontinental lithosphere: Constraints on delamination models: . Earth and Planetary Science Letters 184, $605-621$.

Powell, W. and O'Reilly, S.Y., 2007, Metasomatism and sulfide mobility in lithospheric mantle beneath eastern Australia: Implications for mantle Re-Os geochronology: Lithos (in press).

Ray, J.S., Ramesh, R., and Pande, K., 1999, Carbon isotopes in Kerguelen plume-derived carbonatites: evidence for recycled inorganic carbon: Earth and Planetary Science Letters 170, 205-214.

Rege, S., Jackson, S.J., Griffin, W.L., Davies, R.M., Pearson, N.J., and O'Reilly, S.Y., 2005, Quantitative trace element analysis of diamond by laser ablation inductively coupled plasma mass spectrometry: Journal of Analytical Atomic Spectroscopy 20, 601-610.

Rege, S., Griffin, W.L., O'Reilly, S.Y., Jackson, S.E., Pearson, N.J., Zedgenizov, D., and Kurat, G., 2006, Trace-element patterns of diamond: toward a unified genetic model: Extended Abstract 16th Goldschmidt Conference, Melbourne.

Replumaz, A., Karason, H., van der Hilst, R.D., Besse, J., and Tapponier, P., 2004, 4-D evolution of SE Asia's mantle from geological reconstructions and seismic tomography: Earth and Planetary Science Letters 221, 103-115.

Sautter, V. and Harte, B., 1988, Diffusion gradients in an eclogite xenolith from the Roberts Victor kimberlite pipe: 1. Mechanism and evolution of garnet exsolution in $\mathrm{Al}_{2} \mathrm{O}_{3}$-rich clinopyroxene: Journal of Petrology 29, 1325-1352.

Scambelluri, M., Muntener, O., Ottoline, L., Pettke, T.T., and Vannucci, R. 2004, The fate of B., Bl and Li in the subducted oceanic mantle and in the antigorite breakdown fluids: Earth and Planetary Science Letters 222, $217-234$

Schaefer, B.F., Turner, S., Parkinson, I., Rogers, N. and Hawkesworth, C., 2002, Evidence for recycled Archaean oceanic mantle lithosphere in the Azores plume: Nature 420, 304-307.

Schulze, D.J., 1989, Constraints on the abundance of eclogite in the upper mantle: Journal of Geophysical Research 94, 4205-4212.

Schulze, D.J., Valley, J.W., and Spicuzza, M.J., 2000, Coesite eclogites from the Roberts Victor kimberlite, South Africa: Lithos 54, 23-32.

Schminkler, B., Jacob, D.E. , and Foley, S.F., 2004, Eclogite xenoliths from the Kuruman kimberlites, South Africa: geochemical fingerprinting of deep subduction and cumulate processes: Lithos 75, 173-207.

Shee, S.R., 1978, The Mineral Chemistry of Xenoliths from the Orapa Kimberlite Pipe, Botswana: Unpublished MSc thesis, University of Cape Town, South Africa. 155 pp.

Shervais, J.W., Taylor, L.A., Lugmair, G.M., Clayton, R.N., Mayeda, T.K. and Korotev, R.L., 1988, Early Proterozoic crust and the evolution of subcontinental mantle: eclogites and related rocks from southern Africa: Geological Society of America Bulletin 100, 411-423.

Shirey, S.B., Carlson, R.W., Richardson, S.H., Menzies, A., Gurney, J.J., Pearson, D.G., Harris, J.W., and Wiechert, U., 2001, Archean emplacement of eclogitic components into the lithospheric mantle during formation of the Kaapvaal Craton: Geophysical Research Letters 28, 2509-2512.

Simon, N.S.C., Irvine, G.J., Davies, G.R., Pearson, D.G., and Carlson, R.W 2004, The origin of garnet and clinopyroxene in "depleted" Kaapvaal peridotites: Litho 71, 289-322.

Smith, D., Griffin, W.L., and Ryan, C.G., 1993, Compositional evolution of high-temperature sheared lherzolite PHN1611: Geochimica et Cosmochimica Acta 57, 605-613.

Smyth, J.R. and Caporuscio, F.A., 1984, Petrology of a suite of eclogite inclusions from the Bobbejaan kimberlite, II. Primary phase compositions and origin, in J. Kornprobst (ed.), Kimberlites, II. The mantle and crust-mantle relationships: Elsevier, Amsterdam, 1984, pp. 121-132.

Smyth, J.R., Caporuscio, F.A., and McCormick, T.C., 1989, Mantle eclogites: evidence of igneous fractionation in the mantle: Earth and Planetary Science Letters 93, 133-141.

Snyder, G.A., Taylor, L.A., Croza,z G., Halliday, A.N., Beard, B.L., Sobolev, V.N., and Sobolev N.V., 1997, The origins of Yakutian eclogite xenoliths: Journal of Petrology 38, 85-113.

Sobolev, V.N., Taylor, L.A., and Snyder, G.A., 1994, Diamondiferous eclogites from the Udachnaya kimberlite pipe, Yakutia: International Geology Review 36, 42-64.

Spetsius, Z.V., Belousova, E.A., Griffin, W.L., O'Reilly, S.Y., and Pearson, N.J., 2002, Archean sulfide inclusions in Paleozoic zircon megacrysts 
from the Mir kimberlite, Yakutia: implications for the dating of diamonds: Earth and Planetary Science Letters 199, 111-126.

Stiefenhofer, J., 1993, The petrography, mineral chemistry and isotope geochemistry of a mantle xenolith suite from the Letlhakane DK1 and DK2 kimberlite pipes, Botswana.: Unpublished $\mathrm{PhD}$ thesis, Rhodes University, Grahamstown, South Africa.

Suen, C.J. and Frey, F.A., 1987, Origins of the mafic and ultramafic rocks in the Ronda peridotite: Earth and Planetary Science Letters 85, 183-202.

Taylor, L.A., Keller, R.A., Snyder, G.A., Wang, W., Carlson, W.D., Hauri, E.H., McCandless, T., Kim, K-R., Sobolev, N.V., and Bezborodov, S.M., 2000, Diamonds and their mineral inclusions, and what they tell us: A detailed "pull-apart" of a diamondiferous eclogite: International Geology Review, 42, 959-983.

Thomassot, E., Cartigny, O., Viljoen, K.S., and Harris, J.W., 2006, Methanerelated diamond crystallization in the Earth's mantle: Stable isotope evidence from a single diamond-bearing xenolith: Earth and Planetary Science Letters (in press).

van Achterbergh, E., Griffin, W.L. and Stiefenhofer, J., 2001, Metasomatism in mantle xenoliths from the Letlhakane kimberlites: Estimation of element fluxes: Contrib. Mineral. Petrol. 141, 397-414.

Viljoen, K.S., 1995, Graphite- and diamond-bearing eclogite xenoliths from the Bellsbank kimberlites, Northern Cape, South Africa: Contributions to Mineralogy and Petrology. 121, 414-423.

Viljoen, K.S., Schulze, D.J., and Quadling, A.G., 2005, Contrasting Group I and Group II eclogitic xenolith petrogenesis: Petrological, trace element and isotopic evidence in eclogite, websterite and alkremite xenoliths from the Kaalvallei kimberlite: Journal of Petrology 46, 2059-2090.

Walter, M.J., 1998, Melting of garnet peridotite and the origin of komatiite and depleted lithosphere: Journal of Petrology 39, 29-60.

Wilkinson, J.F.C., 1974, Garnet clinopyroxenite inclusions from diatremes in the Gloucester area, New South Wales: Contributions to Mineralogy and Petrology, 62, 129-139.

Woodland, A.B., Seitz, H.-M., Altherr, R., Marschall, H., Olker, B. and Ludwig, T., 2002, Li abundances in eclogite minerals: a clue to a crustal or mantle origin?: Contributions to Mineralogy and Petrology 143, $587-601$.

Xu, X., O'Reilly, S.Y, Zhou, X., and Griffin, W.L., 1996, A xenolith-derived geotherm and the crust-mantle boundary at Qilin, southeastern China: Lithos 38, 41-62.
William L. Griffin was educated in the USA and spent 20 years at the University of Oslo (Norway) before moving to Australia in 1988. His research ( $>300$ refereed papers) has concentrated on HP/UHP metamorphism (the orogenic eclogites of Norway), the evolution of the subcontinental lithospheric mantle, the origin of diamonds and the genesis of the continental crust. He has been closely involved in the development of in-situ micro-analytical methods for major elements, trace elements and a range of radiogenic and stable isotopic systems in mantle-derived and crustal rocks and ore bodies.

Suzanne Y. O'Reilly was educated in Australia and has been Director of the ARC National Key Centre for Geochemical Evolution and Metallogeny of Continents since 1995. Her research ( $>250$ refereed papers) has spanned basalt geochemistry, the composition and evolution of the upper mantle beneath the continents, the interaction between the continental crust and the lithospheric mantle, and integration of information across the discipline boundaries of geophysics, geochemistry, tectonics and geodynamics. Over recent years, her interests have expanded to include global dynamics and relationships between lithospheric structure and emplacement of giant ore bodies.
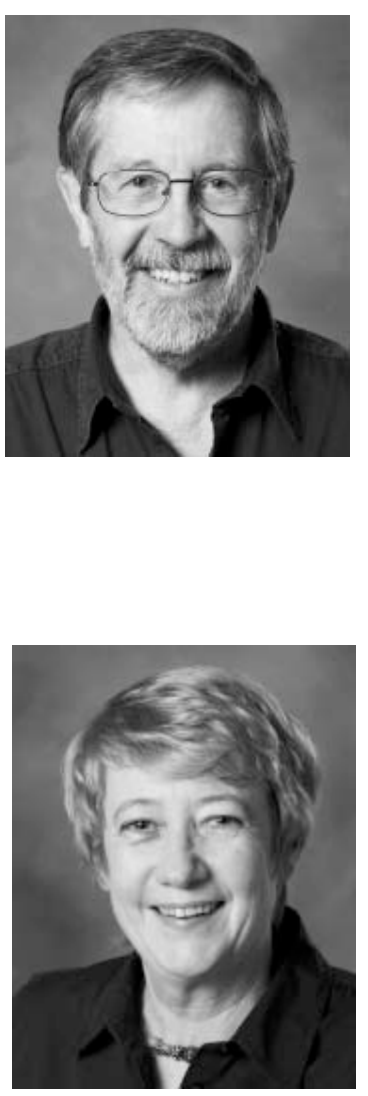

\title{
Joint Meeting PTG - DGG \\ GEO-POMERANIA SZCZECIN 2007
}

24-26 September 2007, University of Szczecin, Poland

Geology cross-bordering the Western and Eastern European Platform

\author{
http://www.geopomerania2007.org \\ http://www.dgg.de
}

Topics:

Southern Permian Basin

Coastal Dynamics

Climate Change

Geoarchaeology
Cross-boundary Groundwater Management

Geopotentials and Resources

Environmental Geology

Geotourism

Conference Secretary:

\author{
Ogarit Uhlmann MSc. \\ F\&U confirm, Permoserstr. 15. 04318 Leipzig, Germany \\ phone: +49 341 / 235-2264, Fax: +49 341 / 235-2782 \\ e-mail: geopomerania@fu-confirm.de
}

